Forthcoming in Julia Pfefferkorn and Antonino Spinelli (eds.), Platonic Mimesis

Reconsidered (Academia). Please cite published version.

\title{
Plato on Poetic and Musical Representation ${ }^{1}$
}

Justin Vlasits (Tübingen)

\section{Introduction}

Plato's most infamous discussions of poetry in the Republic, in which he both develops original distinctions in narratology and advocates some form of censorship, raises numerous philosophical and philological questions. Foremost among them, perhaps, is the puzzle of why he returns to poetry in Book X after having dealt with it thoroughly in Books II-III, particularly because his accounts of the "mimetic" aspect of poetry are, on their face, quite different. How are we to understand this double treatment? Here I will focus on a single aspect of this question, the compatibility of the notion of $\mu$ í $\mu \eta \sigma \varsigma \varsigma$ and its cognates in the two books. As Nickolas Pappas has said, "Whether Books 3 and 10 offer compatible accounts of mimêsis, and how one might make them compatible, remains the most controversial question about Plato's aesthetics". ${ }^{2}$ I will show that there is a single notion of $\mu$ í $\mu$ $\sigma 1 \varsigma$ operative throughout, namely that of representation by resemblance. I will take an unusual tack. I will not begin with the most problematic part of Book III for this interpretation about poetic, linguistic $\mu$ í $\mu \eta \varsigma \varsigma$, but

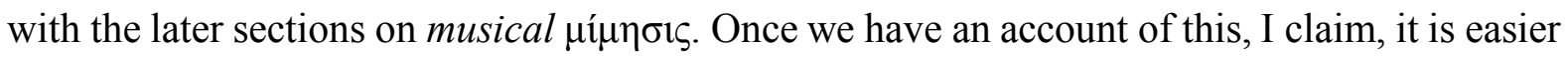

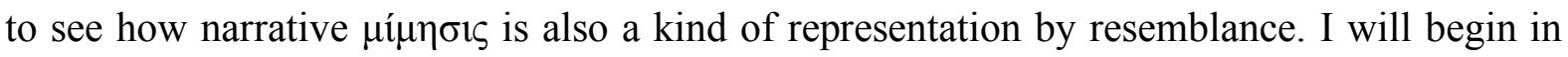
section 2 with the problem posed by the two books and introduce two of the most plausible previous accounts, those of Elizabeth Belfiore and Gabriel Lear. In section 3, I will introduce the notion of representation by resemblance through an examination of Book X. Then in section 4, I will devote significant attention to the non-poetic, musical examples of $\mu$ í $\eta \sigma_{\varsigma}$ in Book III, which received little or no attention in previous accounts, before moving on to the poetic case. I close in section 5 by applying my account to poetic $\mu$ í $\eta \sigma 1 \varsigma$ in Book III.

\footnotetext{
1 Thanks to the audiences at the Platonic Mimesis Revisited conference at Tübingen University, the Higher Seminar in the History of Philosophy at Uppsala University, and the Erlangen Oberseminar for discussion, especially Stefan Brandt, Klaus Corcilius, Gerhard Ernst, Antonio Ferro, Hallvard Fossheim, Stephen Halliwell, Béatrice Lienemann, Erasmus Mayr, M.M. McCabe, Olof Pettersson, Pauliina Remes, Pauline Sabrier, and Oda Tvedt. I am also grateful for conversations with Spencer Klavan and Hong Yu Wong, which have pushed me to contextualize and clarify my discussion in important ways. Jonathan Fine, Julia Pfefferkorn, Antonino Spinelli, and Peter West discussed drafts of the paper and provided enormous help.

${ }^{2}$ Pappas 2017. There is a distinct but related question about the relationship between the two discussions: namely why poetic representation of virtuous people is permitted in Book III but not in Book X. On this, see Moss 2007. In this chapter I will not have space to address this question except insofar as it relates to the possibility that there

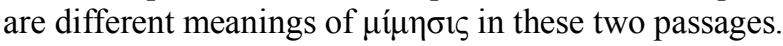




\section{The Problem and Previous Accounts}

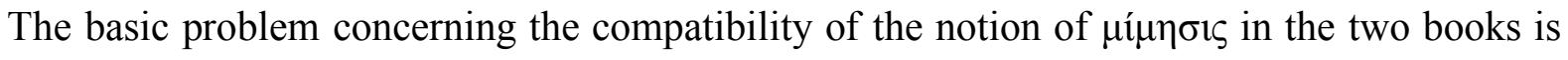
one of extension. In Book III, there are three kinds of poetry, only one of which is mimetic, whereas in Book X all poetry is mimetic. On the Book III account, there are three kinds of poetic narration: simple narration, mimetic, and mixed ( $R$. 392d5-6=T6 infra). In mimetic narration, such as drama, the poet or actor speaks as if they were the person represented by using, for example, first person pronouns to refer to someone other than themselves. In simple narration, as in Sappho, the poet speaks in her own voice. Mixed narration, such as that of Homer, alternates between these two. So, it seems that here, at most two of the three kinds of poetic narration have anything to do with $\mu$ í $\eta \sigma 1 \zeta$.

Book X begins with a striking reference back to III's "banishment of all poetry insofar as it is mimetic" (R. 595a5), which Socrates claims can now be made "more clearly" given the intervening discussion of the soul. However, he proceeds to discuss tragic, epic, and even lyric

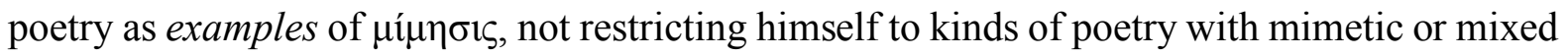
narration. Thus, in Book X, it seems that even poetry with simple narration would count as mimetic. While it might seem that the claim "insofar as it is mimetic" above is restrictive, throughout the discussion Socrates freely includes forms of poetry that were explicitly not classified as mimetic in Book III (e.g., 607a-d).

This puzzle has received two sorts of resolutions in the literature: some claim that Plato shifts

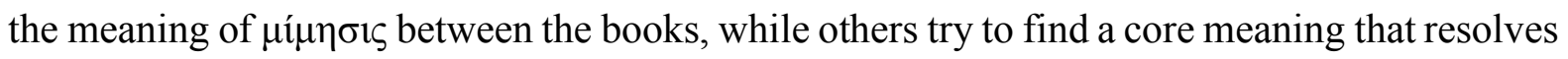
the tension above. ${ }^{3}$ The second sort of solution is generally to be preferred, since the direct back reference at $R$. 595a5 leads the reader to expect a continuity of meaning. Indeed, the motivation for the first type of solution depends on there not being a suitable core meaning shared between the books. I will be arguing for the second type of solution and so will concentrate here on other answers of this type.

According to Elizabeth Belfiore, the core meaning of $\mu$ íf $\sigma \iota_{\varsigma}$ throughout the Republic is "to make one thing like another in sound or shape", which is to be distinguished from being

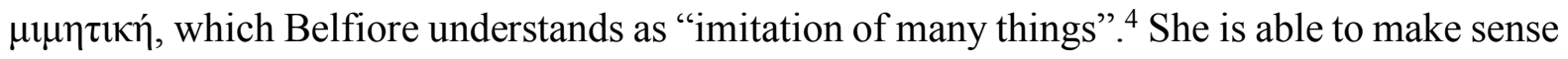

\footnotetext{
${ }^{3}$ Halliwell 2002 is the best representative of the first.

${ }^{4}$ Belfiore 1984, 126.
} 
Forthcoming in Julia Pfefferkorn and Antonino Spinelli (eds.), Platonic Mimesis Reconsidered (Academia). Please cite published version.

of the reference to Book III at $R$. 595a5 by claiming that this was only to do with $\mu$ í $\mu \eta \sigma \mathrm{s}$ of many things. However, this account cannot make sense of the deeper point that Socrates has dramatically expanded the generic range, including epic and lyric poetry indiscriminately under the category of $\mu$ í $\mu \eta \sigma ı$ in Book X, without having done so in Book III. Further, when Plato discusses musical $\mu$ í $\mu$ $\sigma 1 \varsigma$, both beneficial and harmful types of musical modes and rhythms are said to represent one kind of character, following the work of the sophistmusicologist Damon. The case of music, I shall argue in more detail below, is one place where we see Plato's theory of $\mu$ í $\eta$ бis most clearly.

Gabriel Lear describes $\mu$ í $\eta$ $\sigma ı \varsigma$ in terms of creating "an appearance other than an appearance of [oneself]". 5 Here the thought is that those who engage in $\mu$ í $\mu \eta \sigma \varsigma s$ effect a change in their appearance, so that they no longer appear as themselves but as something else. Her emphasis on resemblance between two objects is crucial. However, the idea of changing one's appearance to something else is again not central to cases of $\mu$ í $\mu$ ¡ı $\varsigma$ outside of the poetic realm and arguably does not even occur in cases of simple narration. Again, musical modes do not have an "appearance" that is somehow changed. Plato does not say that the lyre player or the lyre tuning seem to be courageous, for instance, when someone plays a tune on the lyre in the

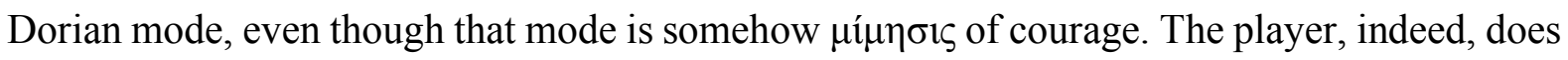
not enter into the account at all and there is nothing else that could plausibly stand for the thing whose appearance is changed. Nor again do paintings, as discussed in either Book III or X explicitly have this feature. Socrates could have said that the painter somehow disguises the medium when painting it, but this does not seem to play any important role in his account of painting, nor should it.

In place of these accounts, I will suggest that we understand $\mu$ í $\mu\rceil \sigma \varsigma$ generally as representation by resemblance. By this, I do not mean that the representation consists in resemblance, which is problematic for the purely logical reason that representation is not symmetric, while resemblance is. Rather, as will become clearer in what follows, the representational aspect is grounded in the resemblance between mimetic object and model. ${ }^{6}$ The connection between $\mu i ́ \mu \eta \sigma ı \varsigma$ and representation has been made in other contexts by Stephen Halliwell, ${ }^{7}$ even though

\footnotetext{
${ }^{5}$ Lear 2011, 201.

${ }^{6}$ For a contemporary account of mimetic images along similar lines to the account presented here, see Kulvicki 2006. The notion that representation requires resemblance played an important role in early modern philosophy of mind. On this, see Fasko/West (2020).

${ }^{7}$ Halliwell 2002, 6 et passim forcefully argues that $\mu$ í $\mu$ $\sigma \varsigma \varsigma$ generally characterizes the "representational" arts, both in their "world-reflecting" and "world-creating" aspects.
} 
Forthcoming in Julia Pfefferkorn and Antonino Spinelli (eds.), Platonic Mimesis

Reconsidered (Academia). Please cite published version.

he is skeptical of its application to Plato's many and varied discussions of $\mu$ í $\mu$ бis. In this paper I do not claim to unify all of the uses even in the Republic, only those in Books III and X which need to be connected for Socrates' argumentation to be successful. In the next section, I will unpack my version of the representation account through a reading of Book X.

\section{Representation by Resemblance in Book X}

After the back reference to Book III, Socrates promises to give an account of $\mu$ í $\mu$ $\sigma ı \varsigma$ in general, surprisingly, perhaps, by focusing on one particular example: painting a picture of a bed. A bed, on Socrates' account, is produced by a craftsman who is looking at the "form of the bed", which in turn was made by a god. The painter, although he does not make a real bed, does make a bed in some sense. ${ }^{8}$ The basic idea, then, seems to be that we can understand $\mu$ í $\mu$ †is through the three beds in the ontological hierarchy: the god's bed, the carpenter's bed, the

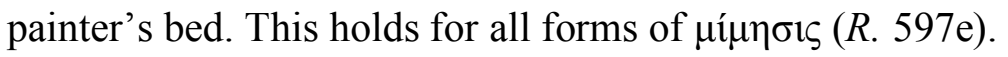

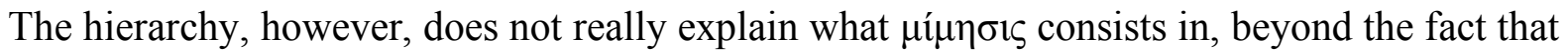
it is, as Socrates says, "at a third remove from the truth". We don't yet know, that is, what one must $d o$ to $\mu \mu \varepsilon \tilde{\tau} \sigma \theta \alpha$ something. This is explained in detail in what follows.

[T1] Now, tell me this about a painter. Do you think he tries in each case to represent $(\mu \mu \varepsilon \varepsilon \tilde{\sigma} \theta \alpha 1)$

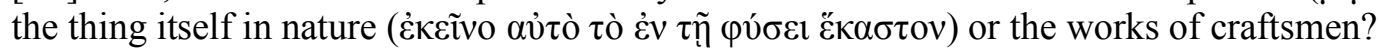

The works of craftsmen.

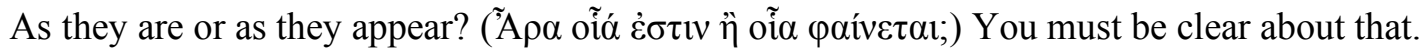
How do you mean?

Like this. If you look at a bed from the side or the front or from anywhere else is it a different bed each time? Or does it only appear different, without being at all different? And is that also the case with other things?

That's the way it is - it appears different without being so.

Then consider this very point: What does painting do in each case? Does it represent in relation

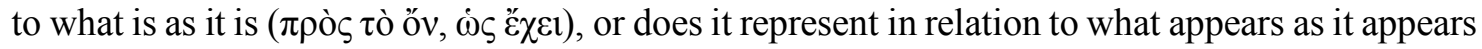

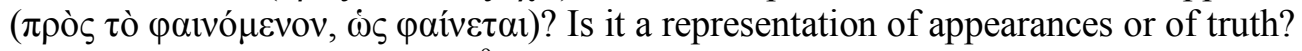

Of appearances. $(R .598 \mathrm{a} 1-\mathrm{b} 5)^{9}$

\footnotetext{
${ }^{8}$ Although this might sound initially strange, it comports well with our ordinary ways, even in English, of talking about art. We might interrupt someone painting, who says "Hold on, I'm finishing the hands.", which would be patently untrue if the "hands" had to be composed of flesh and bone.

${ }_{9}^{9}$ Translations of Plato are those of Cooper/Hutchinson 1996, with sometimes significant alterations. In particular, I translate cognates of mimeisthai with cognates of "represent". The Greek text of the Republic used is that of Slings 2003.
} 
Forthcoming in Julia Pfefferkorn and Antonino Spinelli (eds.), Platonic Mimesis Reconsidered (Academia). Please cite published version.

T1 answers two central questions about the process of $\mu$ í $\mu$ $\sigma 1$, , which together entail that Plato is understanding $\mu i ́ \mu \eta \sigma ı \varsigma$ as representation by resemblance. First, the model of a $\mu$ í $\mu \eta \imath_{\varsigma}$ is not a form. This distinguishes the painter from the carpenter, who, on Socrates' account, uses the form of the bed as his model. Second, an act of $\mu$ í $\mu$ ¡ı merely as it appears, with the result that the product is like the model with respect to its appearance. $^{10}$

While this account seems pretty plausible when it comes to painting a bed, it becomes somewhat strained when applied in general to all forms of $\mu$ í $\mu$ бis. When I compose a tune with rhythm and melody, is there something sensible which I consider and whose appearance is recreated in that rhythm or melody? What about a poem? If the answer is yes, as it apparently must be if this account is as general as Plato insists that it is, we must understand the "model" and its "appearance" in very abstract, structural terms.

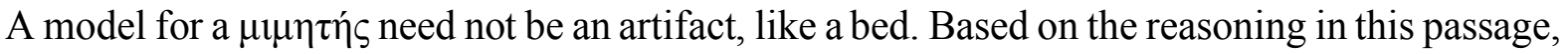
it can also be something found in the natural world, such as a person or a mountain. While there is, in general, significant dispute about whether Plato is committed to forms of artifacts, ${ }^{11}$ in this passage it is absolutely essential to the argument that there is a form of bed. In general, it seems that a model can be anything that participates in a form and can thus be multiple. ${ }^{12}$ This is compatible with the idea that the $\mu \mu \eta \eta$ '́ s takes their models from craftsmen, since in many places (especially the Timaeus 28a-29a, Philebus 27b, and Sophist 265a-e), the natural world is said to be the product of a craftsman. But what can we glean about the "modeling" relation from this passage? I suggest that it is best understood as the relation of representation. For Socrates explains that, whether the model is a form or a participant, one's product is in

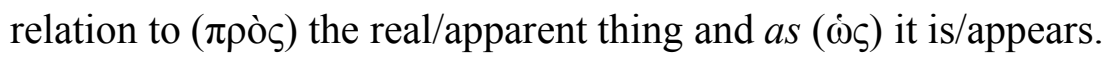

Second, the "appearance" of that model must be understood in a quite general way. ${ }^{13}$ Plato does seem here to be focusing on sensible qualities, but if we are to apply this account to poetry,

\footnotetext{
10 Socrates doesn't give any examples of how one might " $\mu \mu \varepsilon \tilde{\sigma} \sigma \theta \alpha \imath$ $\pi \rho$ ò $\varsigma$ ò őv". However, there is a parallel

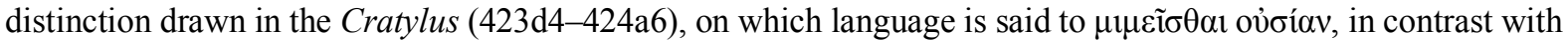
the arts, which only do so for sensible qualities. It is not clear to me whether Socrates endorses this account of language in either dialogue. However, the distinction drawn in the $R$. X passage leaves open that possibility for such an account of linguistic representation. For more on the Cratylus, see Pavani's contribution to this volume. ${ }^{11}$ See, for example, Aristotle's De ideis (Alex. Aphr. In Metaph. 80,5-6).

${ }^{12}$ It is here where we get one of the few explicit mentions of the "one over many" principle $(R$. $596 \mathrm{~d})$ as well as an argument for the uniqueness of forms $(R .597 \mathrm{~b}-\mathrm{c})$.

${ }^{13}$ One question about how to understand "appearances" here that I want to leave open is whether they are mindindependent properties of art objects or somehow dependent on the mind of the observer and/or artist. In most of these passages, it seems to me that Plato speaks as if the former were the case. However, in Sph. 235d4-236b7, he seems to make a distinction precisely along these lines between cases of $\mu$ í $\mu$ $\sigma ı \varsigma$ that preserve the correct
} 
Forthcoming in Julia Pfefferkorn and Antonino Spinelli (eds.), Platonic Mimesis Reconsidered (Academia). Please cite published version.

we would have to say that, in some sense, the language sounds like what it is modeled upon. That is, we do not want to say that the word "dog" sounds like a dog. Rather, taking into account the performance context, the most that can be said is perhaps that the words spoken by an actor sound similar to how they would sound if spoken by the character played by that actor. At first this might seem completely outlandish. We don't want to saddle Socrates with the idea that spoken words must bear sensible resemblance to material objects, or worse, immaterial things like character traits. We should be careful here to distinguish what we might want to call the merely linguistic aspect of poetry, which it has in common with prose, and its poetic aspect. ${ }^{14}$ Socrates himself explains this difference in Book III as the difference between metrical and non-metrical language, when he changes the speech of Chryses to simple narration. For there

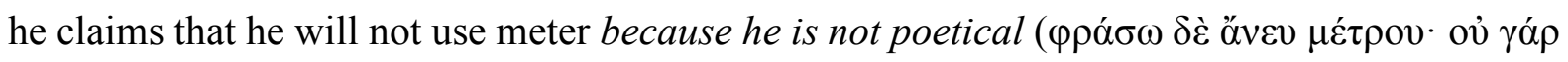

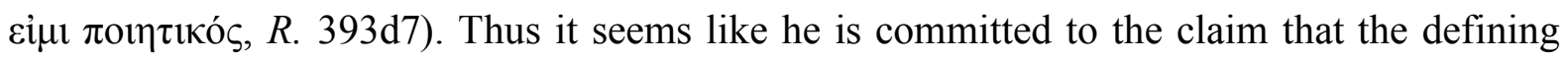
feature of poetry is meter. So in saying that all poetry is $\mu$ í $\eta_{\sigma} \varsigma \varsigma$ of appearance, he is presumably saying something about poetic meter. While it is nevertheless unclear how this will work in practice, that is, what the meter is supposed to represent by resemblance, we have no longer the problem of saying that the words themselves must resemble what they represent. As will be clear below, it seems most likely that Plato understood meter in much the same way as he understood rhythm. ${ }^{15}$

In suggesting that Socrates gives this account, I do not mean that it is without its problems. In particular, the appeal to resemblance has been subjected to a thorough critique in contemporary aesthetics by Nelson Goodman, who claims it to be a "most naïve view of representation"16. Goodman's fundamental objection to resemblance accounts of representation is that they cannot accommodate the fact that everything resembles everything else in some respect. Thus, while there are respects in which a picture (for example) resembles its subject, there are also respects in which it resembles any other arbitrary thing, and there is no reason to prefer the ways in which it resembles its subject as opposed to anything else.

I do not want to suggest that Plato has a response to this worry in exactly the form in which Goodman puts it. However, he does clearly engage with related issues in a variety of dialogues

proportions and thus objectively correlate to the model, and those in which this merely seems to be the case. On this passage, see Lienemann 2010, $275 \mathrm{ff}$. and Strobel in this volume.

${ }^{14}$ For such a distinction, see Aristotle Po. 1447a19-29.

${ }^{15}$ For the extremely tight connection between rhythm and meter in Greek music, see West 1992, 129-159 and D'Angour 2015, 193-7.

${ }^{16}$ Goodman 1976, 3. 
Forthcoming in Julia Pfefferkorn and Antonino Spinelli (eds.), Platonic Mimesis Reconsidered (Academia). Please cite published version.

that could indicate something of a response. In the Protagoras, for example, we see Protagoras claim that "anything at all resembles any other thing in some way" (Prt. 331d), even polar opposites like white and black. Indeed, the compresence of opposites apparently validates at least one version of the Goodman claim, since every sensible thing is both like and unlike (Prm. 127e ff.). The Parmenides, as a whole, shows how puzzles about similarity and difference cut to the very heart of Plato's theory of forms with the likeness regress argument (Prm. 132c133a). ${ }^{17}$

So it seems to me that the Goodman-type worries are not out of place. ${ }^{18}$ There are several points Plato could make in response to Goodman. First, he could, as above, distinguish between resemblance grounding the representation and the representation consisting in resemblance. For the former kind of view, it is possible that there is more to something being a representation than merely that there is a resemblance relation. On its own, however, this does not help so much, since if any sort of resemblance would work, then we still would have the problem that the content of the representation would be left underdetermined. However, given Plato's interest in perceptually salient similarities, we might be able to restrict the notion of resemblance sufficiently that mimetic relations won't hold between any two objects whatsoever. This may not constitute of a complete response to Goodman's worries, but it is at least the beginnings of a response.

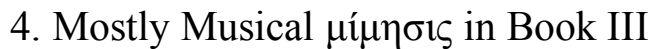

I have argued that the $\mu$ í $\mu \eta \sigma \varsigma$ in Book $\mathrm{X}$ is best understood as representation by resemblance and will now aim to extend this analysis to the various applications of the notion of $\mu$ í $\mu \eta \sigma \varsigma$ in Book III. I will first treat the musical examples for two reasons. First, these examples have been largely neglected in discussions of $\mu$ í $\mu \eta \iota_{\varsigma}$ in the Republic, which have focused almost exclusively on the poetic and pictorial examples. ${ }^{19}$ This despite the fact that the musical arts were among the first to be characterized as mimetic. ${ }^{20}$ Indeed, the probably very first use of

\footnotetext{
${ }^{17}$ On the notion of resemblance in Plato's metaphysics and its connection to problems in Goodman, see Ch. 12 of Lienemann 2010.

18 Thanks to Stephen Halliwell for pressing the Goodman objection and M.M. McCabe for suggesting the relevance of the broader metaphysical questions to its answer.

${ }^{19}$ Since Schofield 2010 made the same complaint over a decade ago, there has been little change in the situation. There have been, however, a number of important studies of the role of music in Platonic education: Woerther 2008 and Pelosi 2010, Ch. 1.

${ }^{20}$ See Halliwell 2002, $15 \mathrm{ff}$.
} 
Forthcoming in Julia Pfefferkorn and Antonino Spinelli (eds.), Platonic Mimesis

Reconsidered (Academia). Please cite published version.

the $\mu$ u-root in Greek in the Homeric Hymn to Apollo (162-4) describes the way that the song and dance of the Delian maidens represent the voice and rhythm of all men. ${ }^{21}$ Second, as we will see in the next section, the account of rhythm will actually resolve difficulties in Plato's account of poetic $\mu$ í $\mu$ ¡is. The consideration of music thus seems to me to be necessary for a complete understanding of Plato's account of mimetic arts generally.

We begin at the transition to music at 398b6-c2, where Socrates announces that he has

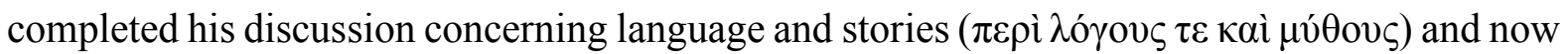

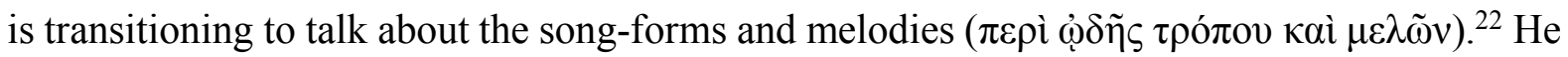
then proceeds to analyze this in broadly three dimensions: harmony and rhythm, and instrumentation, arguing that they will follow the same patterns. Socrates does not assume at the outset that these are going to be given mimetic analyses, but as we will see, he will do so. After suggesting that the modes appropriate to lamentation (Mixolydian and Syntonolydian) and those "soft" modes appropriate to drinking parties (Ionian and Lydian) are to be jettisoned, only the Dorian and Phrygian modes are left. After this, he gives a more general set of

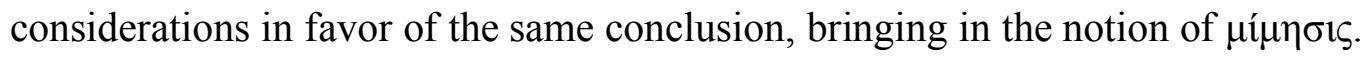

[T2] I don't know all the musical modes. Just leave me the mode that would suitably represent the tone and rhythm of a courageous person who is active in battle or doing other violent deeds, or who is failing and facing wounds, death, or some other misfortune, and who, in all these circumstances, is fighting off his fate steadily and with self-control. Leave me also another mode, that of someone engaged in a peaceful, unforced, voluntary action, persuading someone or asking a favor of a god in prayer or of a human being through teaching and exhortation, or, on the other hand, of someone submitting to the supplications of another who is teaching him and trying to get him to change his mind, and who, in all these circumstances, is acting with moderation and self-control, not with arrogance but with understanding, and is content with the outcome. Leave me, then, these two modes, which will best represent the violent or voluntary utterances of those who are moderate and courageous, whether in good fortune or in bad. ${ }^{23}(R .399 \mathrm{a} 5-\mathrm{c} 4)$

21 The interpretation of this passage is controversial. However, there has been a general trend towards understanding " $\mu \mu \varepsilon \tilde{\imath} \sigma \theta$ "” in terms of representation rather than copying in e.g., Peponi 2009, Halliwell 2002, 15 ff. Peponi 2009, 64, however, thinks that the "voice and rhythm" is only the means of representation, not the end. However, this seems in conflict with the verse 163, where the bard observes "to each it would seem that they themselves were uttering", which seems to suggest similarity (indeed, indistinguishability) between the means of representation and the ends.

${ }^{22}$ According to Reeve's translation, there is a generic shift to "lyric odes and songs", but what follows does not seem to be restricted to such genres and apparently applies to any of the many poetic genres which were set to music. Indeed, it would be very strange on this translation that Socrates requires that the music follow the words (398d), a clear back reference to the earlier section.

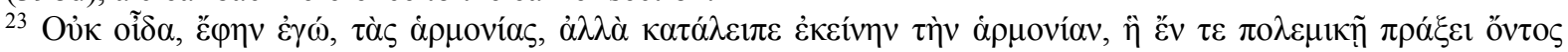

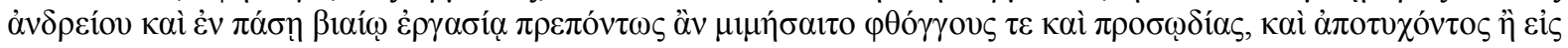

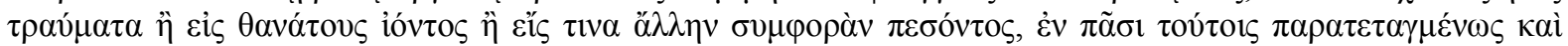

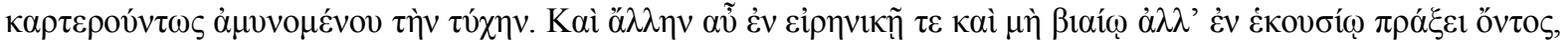

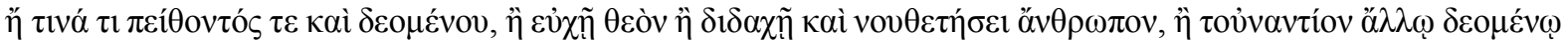

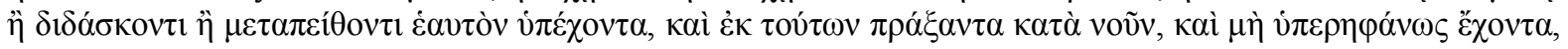


Forthcoming in Julia Pfefferkorn and Antonino Spinelli (eds.), Platonic Mimesis Reconsidered (Academia). Please cite published version.

In this passage, I suggest, $\mu$ í $\mu \eta \sigma ı \varsigma$ is used in a way very close to that of Book X. ${ }^{24}$ First, we should note that Socrates moves freely between talking of a mode "representing" a character and a mode being of that character, using here clearly the objective genitive, much in the way that a painting or a thought is of its subject. This language seems to me to be very much in line with the way that representational notions appeared in the bed-passage of Book X. ${ }^{25}$ Moreover,

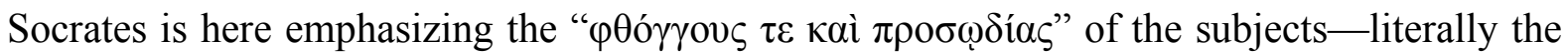
sounds and variations in pitch that issue from a moderate or courageous person, presumably in speech. ${ }^{26}$ That is to say, the proper objects of harmonic $\mu$ í auditory. The musical sound (whether vocal or auditory) is similar to and thereby represents the vocal cadence of a person with a certain character trait (say, courage) in a context in which that character trait shines through (say, war). Plato's point here seems to parallel quite closely the account of the maidens' mimetic abilities in the Homeric Hymn to Apollo:

They know how to represent the voices of all men and the castanets rattling.

To each it would seem that they themselves were uttering.

This is how their beautiful song was composed. ${ }^{27}(162-4$, my translation)

The fact that Plato, like the author of the hymn, is emphasizing the particularly auditory qualities (the cognates of $\varphi \theta \varepsilon \dot{\gamma} \gamma \varepsilon \sigma \theta \alpha \mathrm{l}$ are particularly notable in this context) of the subject strongly suggests that the manner of representation is through resemblance. If mimetic representation need not be mediated by some resemblance, then the fact that the sound represents some other sound and not, say, a color, would be completely incidental. That is to say, what determines the content of the representation (e.g., the fact that the Dorian mode represents the courageous tone of voice) derives from the auditory similarity between the mode and the cadences of a courageous person.

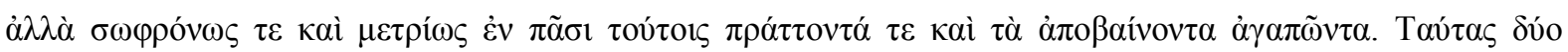

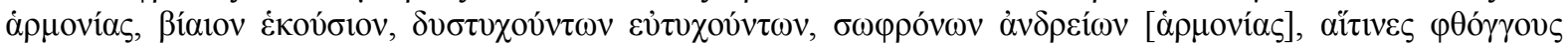

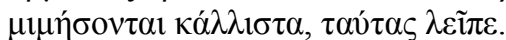

${ }^{24}$ Pace Schofield 2010, 242, who surprisingly claims that in Book III, music is representational but that poetic

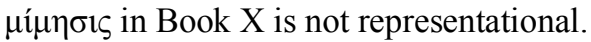

${ }^{25}$ For the representational aspect of music, see Klavan 2019 and Woerther 2008. There is some oscillation in the

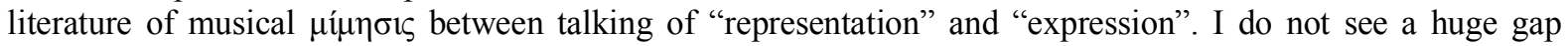
between these two, but insofar as "representation" makes more sense of the continuity between music, painting, and poetry, which are all described as mimetic in Book III.

${ }^{26}$ Schofield $2010238 \mathrm{ff}$.

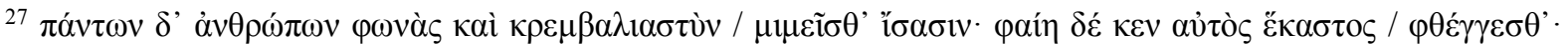

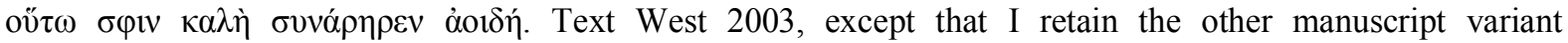

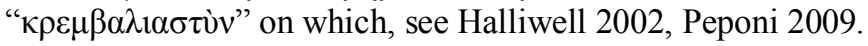


Forthcoming in Julia Pfefferkorn and Antonino Spinelli (eds.), Platonic Mimesis Reconsidered (Academia). Please cite published version.

This point is perhaps best appreciated by comparing Plato's account of musical representation with Aristotle's in the Politics, which contains a superficially very similar account of harmonic representation, where different harmonies again correspond to different character traits. ${ }^{28}$ There he claims that melody differs from painting in that, while the latter can only depict character and emotion via shapes and colors that are "signs" of character, melodies directly represent character traits (1340a30-b10). This, for Aristotle, explains the very special way in which music affects us. While Aristotle's account does seem well-positioned to explain the particularity of music, it does so at a cost. It is difficult on this account to see exactly how a harmony can manage to represent in this way. If we say it is by mathematical proportion, then it would seem that anything with such a proportion would represent in the same way, but this of course is exactly the opposite as what Aristotle originally wanted. Plato's view, by contrast, treats music in essentially the same way that Aristotle's account treats painting.

Finally, it is worth noting in detail the problem that this passage raises for accounts such as those of Belfiore and Lear. Pace Belfiore, here we have clear cases of $\mu$ í $\mu \eta \sigma ı$ of one type of thing: the Dorian mode, for example, represents courageous speech. While there can surely be more than one instance of courageous speech, it is clear that the musical mode represents the type. This is compatible with Book X's account since the courage that is being represented here is clearly not the form, but the sensible manifestation. Moreover, it is not plausible to see here Lear's notion of making oneself appear other than one is, since a musical mode is not the sort of thing that could change its appearance. An instrument could change its tuning, but here the claim is not about the instrument but its attunement. Indeed, while she is correct that appearances are fundamentally involved, she is incorrect in thinking that $\mu \mu \eta \dot{\eta} \mu \alpha \tau \alpha$ can appear in more than one way. While this is certainly true in the case of a tragic actor, the musical modes do not have this feature.

After his account of the musical modes, Socrates makes what initially seems like a digression from the program of discussing harmony and rhythm by discussing appropriate instrumentation.

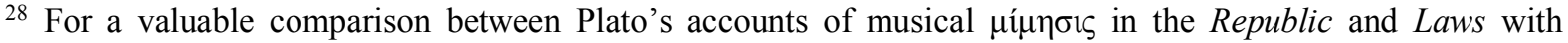
Aristotle's account, see Woerther 2008, who correctly notes that for Aristotle, "musical mimesis alone can imitate characters directly" (100), a point which is missed by Halliwell 2011.
} 

Reconsidered (Academia). Please cite published version.

[T3] What about flute-makers and flute-players? Will you allow them into the city? Or isn't the flute the most "many-stringed" of all? And aren't the panharmonic instruments all representations $(\mu i \mu \eta \mu \alpha)$ of it? ${ }^{29}(R .399 \mathrm{~d} 3-5)$

This passage is difficult for any interpretation, because here we are getting some kind of mimetic relation holding between two kinds of instruments. Nevertheless, I think my interpretation can make best sense of this. The panharmonic instruments were 1) developed with the aulos as a model (hence might be taken to imply some kind of representation) and 2) in particular aimed to have the same harmonic range. ${ }^{30}$ We cannot understand " $\mu$ í $\mu \eta \mu \alpha$ " here as meaning something like "copy" in a straightforward sense, since then the panharmonic instruments would just be more auloi, not different kinds of instrument. Rather, we need to see the makers of instruments as aiming to replicate the auditory aspects of the aulos, in particular its ability to modulate. Thus, it seems to me that the account of representation by resemblance actually does a pretty good job of explaining why Plato chose here the language of $\mu$ í $\mu \eta \sigma \mathrm{s}$, since the newer instrument's range is similar to the aulos, which in turn stood as a kind of "model" for it.

Because Plato was particularly interested in the harmonic aspects of different instruments, it made sense for him to treat them in the section on harmony. ${ }^{31}$ After this, he transitions smoothly, as we would expect, to the discussion of the remaining topic: rhythm.

[T4] Following the musical modes it is our ask to discuss the regulation of rhythm. We shouldn't strive to have either subtlety or great variety in metrical feet. Rather, we should try to discover what are the rhythms of someone who leads an ordered and courageous life and, knowing these, force the meter and the tune to follow his words, not his words to them. What these rhythms actually are is for you to say, just as in the case of the modes.

I really don't know what to say. I can tell you from observation that there are three basic kinds of metrical feet out of which the others are constructed, just as there are four in the case of pitches. But I can't tell you which sort represents which sort of life.

Then we'll consult with Damon as to which metrical feet are suited to slavishness, insolence, madness, and the other vices and which are suited to their opposites. I think I've heard him talking about an enoplion, which is a composite metrical phrase (although I'm not clear on this), and also about dactylic or heroic meter, which he arranged, I don't know how, to be equal up and down in the interchange of long and short. I think he called one foot an iambus, another a trochee, assigning a long and a short to both of them. In the case of some of these, I think he approved or disapproved of the tempo of the foot as much as of the rhythm itself, or of some combination of

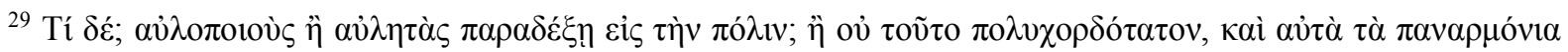
$\alpha$ $\lambda$ oṽ $\tau \vartheta \gamma \chi \alpha ́ v \varepsilon ı ~ o ̋ \tau \tau \alpha \mu i ́ \mu \eta \mu \alpha$;

${ }^{30}$ I have not been able to confirm Socrates' claim that historically auloi served as models for instruments like the trigonos or polychord kithara. The latter, however, were primarily associated with the "New Music" of the late $5^{\text {th }}$ century, while the earliest aulos representations date from the $8^{\text {th }}$ century (West 1992, 82, 366-8).

${ }^{31}$ The connection between instrumentation and musical modes is made very clear in Lynch 2016, who shows that the modes that Plato accepts in this passage are exactly those that can be played on the lyre, whereas those rejected are particularly designed for the aulos.
} 
Forthcoming in Julia Pfefferkorn and Antonino Spinelli (eds.), Platonic Mimesis Reconsidered (Academia). Please cite published version.

the two-I can't tell you which. But, as I said, we'll leave these things to Damon, since to mark off the different kinds would require a long argument. Or do you think we should try it? ${ }^{32}(R$. $399 \mathrm{e} 7-400 \mathrm{c} 6)$

Despite the sketchiness of the account of rhythm here in comparison to what we find in the section on harmonics, the mimetic principles are exactly the same. What is difficult in this case is the rhythmic theory, but the basic ethical and psychological criteria that Socrates and Glaucon had discussed for harmonics are still operative. Here we are looking for the rhythm of someone orderly and courageous, and the objective genitive, as I have already argued, strongly suggests some notion of representation because the way that a courageous person moves stands as some kind of model for the rhythm.

We do not get any specific information about how this representation comes about, whether it is by resemblance or not. However, comparison with the discussion of rhythm in the Laws provides some help. ${ }^{33}$ There dance is fundamentally connected with rhythm ( $\left.\mathrm{Lg} .673 \mathrm{~d}\right)$ and is said to concern the movements of various sorts of people. The Pyrrhic, for example, represents the motions of those engaged in war and seems to consist in motions that in some way resemble the motions of someone in battle $(\operatorname{Lg} .814 \mathrm{e}-815 \mathrm{e})$. If this is so, one would expect the rhythms of such music also to somehow resemble the pattern of movement of battle. Socrates does not give such an account of rhythm in the Republic, but it seems to fit well with the sort of account that he gave of harmony.

The last discussion of $\mu$ í $\mu$ $\sigma 1 \varsigma$ occurs when discussion turns away from music to the more

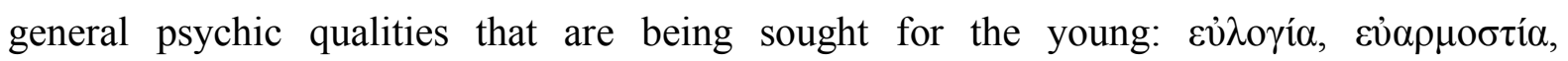

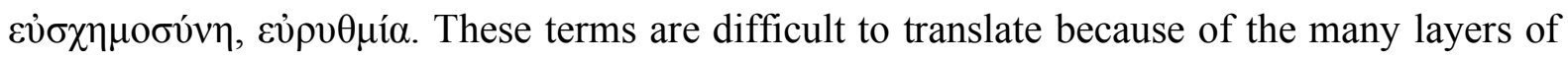
meaning implied by them. Each term refers to a notion from the previous musico-poetic

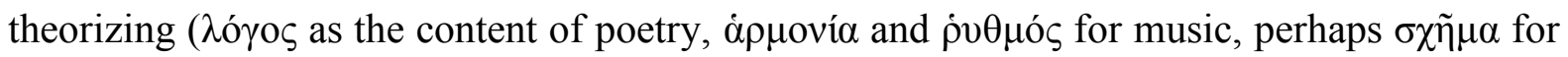

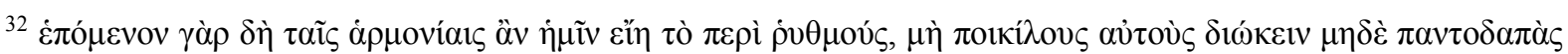

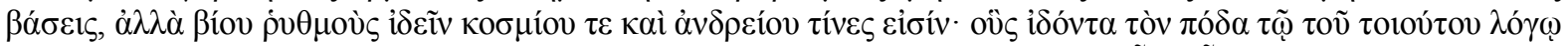

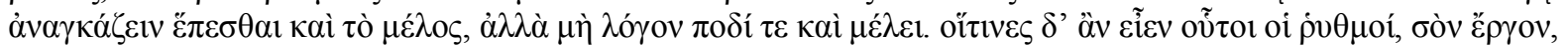

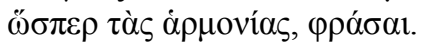

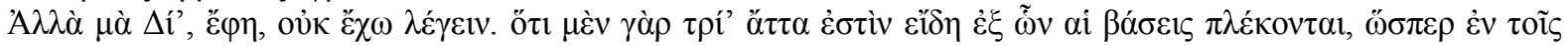

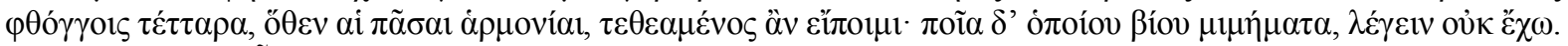

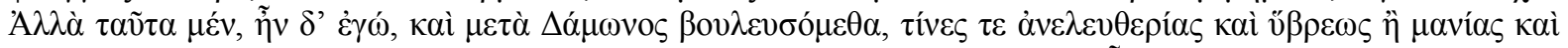

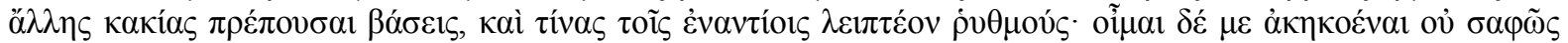

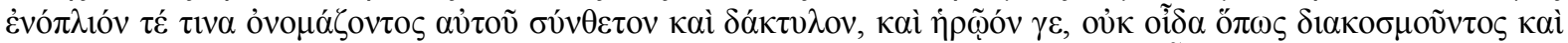

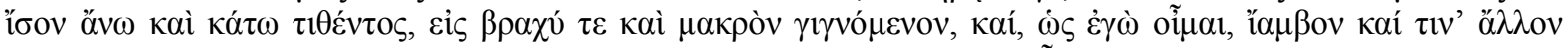

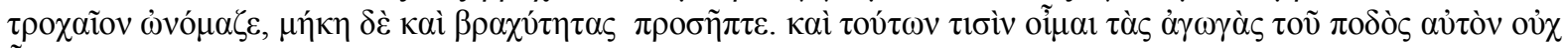

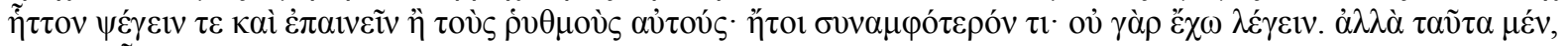

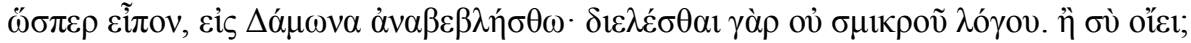

${ }^{33}$ For more on this issue, see Julia Pfefferkorn's contribution to this volume.
} 
Forthcoming in Julia Pfefferkorn and Antonino Spinelli (eds.), Platonic Mimesis Reconsidered (Academia). Please cite published version.

dance?), and the abstract nouns formed with " $\varepsilon$ '" imply that these are done well as opposed to poorly. However, these terms also have broader ethical connotations, which is why Socrates can claim that they are features of the soul. Furthermore, he is able use this characterization to extend his discussion beyond the musico-poetic:

[T5] Now, surely painting is full of these qualities, as are all the crafts similar to it; weaving is full of them, and so are embroidery, architecture, and the crafts that produce all the other furnishings. Our bodily nature is full of them, as are the natures of all growing things, for in all of these there is grace and gracelessness. And gracelessness, bad rhythm, and disharmony are akin to bad words and bad character, while their opposites are akin to and are representations of the opposite, a moderate and good character. ${ }^{34}(401 \mathrm{a} 1-8)$

Here, I conclude, we see the same pattern that we have been seeing so far in Book III. We can see the idea of representation by resemblance nicely expressed by the hendiadys " $\alpha \dot{\delta} \delta \varepsilon \varphi \alpha \dot{\alpha} \tau \varepsilon$

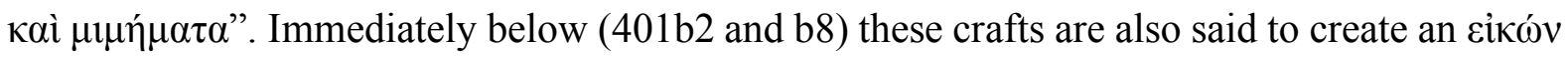
of the good or bad person or character trait. Again, it seems to me that the crafts do not represent these qualities in abstraction, but rather embodied and sensible instantiations of them. The basic idea is then that the way to instill these good character traits in the young is by presenting them with representations of instances of those traits by aesthetic qualities similar to them, which are found in all of the mimetic arts when done well. By looking at a painting, for example, of a person acting with grace, we contemplate the grace that is represented by the painting and our souls are thereby improved..$^{35}$

\section{Poetic Representation in Book III}

If what I said in sections 3 and 4 is correct, Plato is using " $\mu$ í $\mu \eta \sigma \varsigma$ " terminology in the same way at the end of Book III and the beginning of Book X. Thus, someone who posits a distinct use in the Book III discussion of poetry must not only say that the two books are inconsistent with one another, they must also claim that there is inconsistency within Book III itself. While

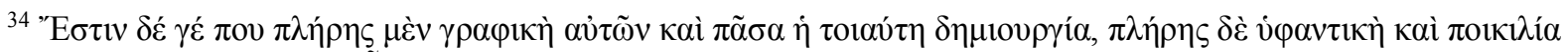

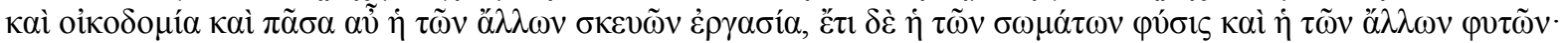

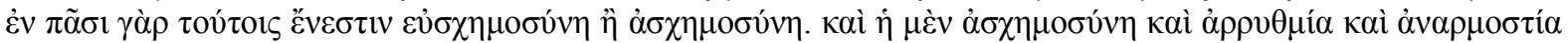

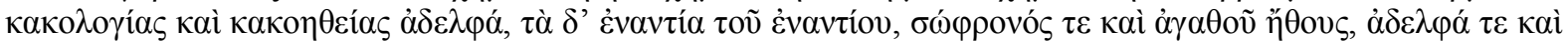
$\mu \mu \eta \dot{\mu} \mu \alpha \alpha$.

35 By framing this in terms of "representation" I do not mean to make this out to be a highly intellectual or reflective process. Representing something as graceful could involve little more than finding it to be beautiful upon seeing it. Thanks to Jonathan Fine for pressing me on this point.
} 
Forthcoming in Julia Pfefferkorn and Antonino Spinelli (eds.), Platonic Mimesis Reconsidered (Academia). Please cite published version.

it is not problematic if the meanings of terms shift in general, in this case, it would matter quite a lot. Socrates sees himself as giving tightly connected, parallel arguments about poetic style, musical modes, and rhythm based on the idea that these are all mimetic. If the notion of $\mu$ í $\mu$ irs itself were not stable within this argumentative web, that would be highly problematic for Socrates' project. What I aim to show now is that the mimetic aspects of poetry that are discussed in III are consonant with the foregoing account.

I begin with the division that drives the problem:

[T6] And aren't these narratives either narrative alone, or narrative through representation, or both ${ }^{36}(R .392 \mathrm{~d} 5-6)$

To repeat the puzzle that began the paper, how is it that here just one form of poetry can be mimetic while in Book X poetry as a whole is? Two things must be shown. First, we need to see why this passage is not inconsistent with the account in Book X. But this merely negative point is not sufficient for the argumentative aims of this paper, since we need some reason to think that the accounts are not merely consistent, but substantially the same.

The first point, it seems to me, can be dealt with relatively quickly, drawing on a point made by Gabriel Lear, who claims: "Thus from the fact that there are some poems that are not mimetic when it comes to narration, it simply does not follow that there is any poetry that is utterly non-mimetic." This point shows what is wrong with the most basic way of stating the puzzle above: the trichotomy of simple, mimetic, and mixed narration would only be inconsistent with the claims of Book $\mathrm{X}$ if poetry were exhausted by narration. ${ }^{37}$ But this is plainly false, since it neglects linguistic features of poetry such as meter as well as nonlinguistic features such as musical accompaniment, which were deeply intertwined with Greek poetic practice.

The second point, however, requires a more thorough discussion of Plato's conception of mimetic narration and poetry in general. We begin with how he describes mimetic narration.

[T7] [T]he poet himself is speaking and doesn't attempt to get us to think that the speaker is someone other than himself. After this, however, he speaks as if he were Chryses and tries as far as possible to make us think that the speaker isn't Homer but the priest himself-an old man.

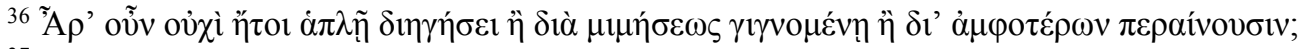

${ }^{37}$ Halliwell 2009 defends an even stronger view that the typology in book III does not amount to a complete theory of narrative at all.
} 
Forthcoming in Julia Pfefferkorn and Antonino Spinelli (eds.), Platonic Mimesis

Reconsidered (Academia). Please cite published version.

And he composes pretty well all the rest of his narrative about events in Troy, Ithaca, and the whole Odyssey in this way.

That's right.

Now, the speeches he makes and the parts between them are both narrative?

Of course.

But when he makes a speech as if he were someone else, won't we say that he makes his own style as much like that of the indicated speaker as possible?

We certainly will.

Now, to make oneself like someone else in voice or appearance is to represent the person one makes oneself like.

Certainly.

In these passages, then, it seems that he and the other poets effect their narrative through representation.

That's right.

If the poet never hid himself, the whole of his poem would be narrative without representation. ${ }^{38}$ (R. 393a6-d1)

What is Homer described here as doing in the speech of Chryses? Narrating as if (ळ̋ऽ or $̋ \sigma \pi \varepsilon \rho)$ he were the one speaking. It does not seem that this "as if" mode is anything like fooling the audience that Chryses is speaking instead of Homer. Rather, the suggestion is that Chryses giving his own speech would differ from Homer merely narrating its content in his own voice. Perhaps the most notable difference would be the difference in the use of the first-person pronouns, which would have different referents in the two kinds of speech. It seems to me that the best way to capture this difference is by thinking of the "as if" in terms of selfrepresentation..$^{39}$ That is, when a speaker engages in mimetic narration, in their speech they represent themselves as the "other".

Moreover, Homer is said to be doing this by "making his own style as much like that of the indicated speaker as possible" and this way of making his own style similar to another's is said

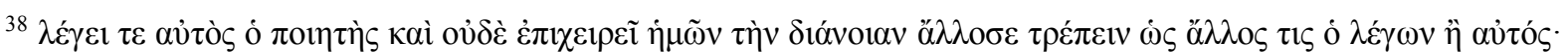

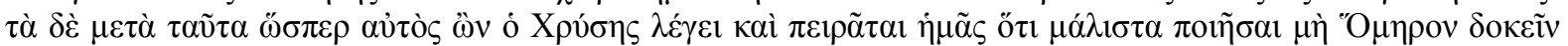

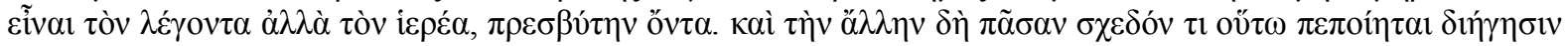

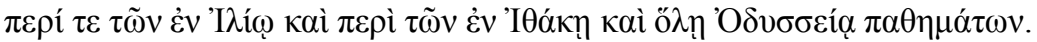

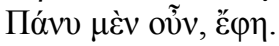

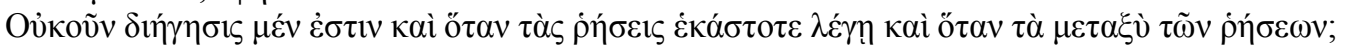

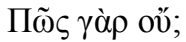

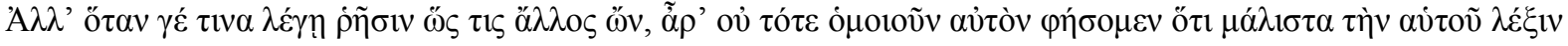

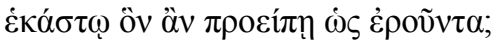

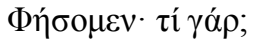

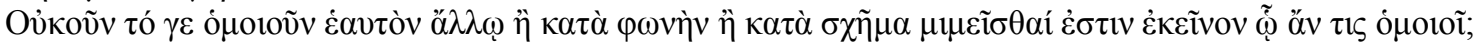

Tí $\mu$ ńv;

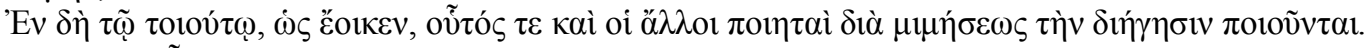

Пóvv $\mu \bar{\varepsilon} v$ ỡv.

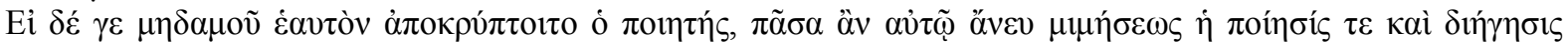

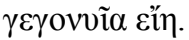

${ }^{39}$ M.M. McCabe has developed these points in detail in her Sather lectures, which have not yet been published.
} 
Forthcoming in Julia Pfefferkorn and Antonino Spinelli (eds.), Platonic Mimesis Reconsidered (Academia). Please cite published version.

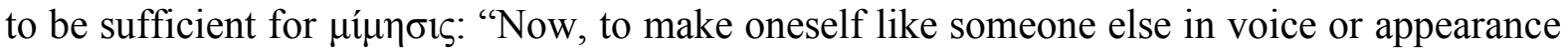
is to represent the person one makes oneself like". This is, I submit, the language of representation by resemblance par excellence. Indeed, it closely resembles the language of the

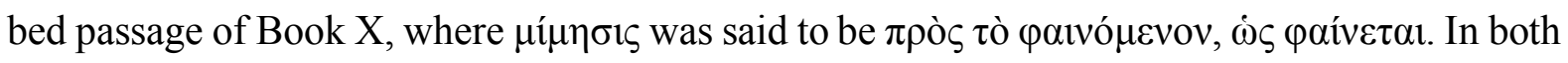
passages, then, we see not just consistent notions of $\mu$ í $\mu$ $\sigma \iota s$, but really the very same notion. Although this passage in some ways conforms to Lear's account, since here it really does seem to be a case of making oneself similar to something else, that is due to a particularity of this case and not of $\mu$ í $\eta_{\sigma i \varsigma}$ in general. For here we have a confluence of the subject and object of the representation: Homer and Chryses are both people. When that happens, to create the similarity required for the representation, Homer's appearance (in this case, his voice and speech patterns) must in some way change. But $\mu$ í $\eta \sigma 1 s$ in general does not have this feature, since the subject and object of a representation can be very different kinds of things: a musical mode and a character trait, for example. In these cases, no change is necessary in the appearance of the subject in order for it to represent its object.

If what I have said about Book X is correct, however, I must nevertheless give a fuller account of how poetry with simple narration will be an example of $\mu$ í $\mu$ jis. It must first be acknowledged that Plato does not claim that it is so in this passage. However, how clearly Book $\mathrm{X}$ subsumes all poetry under the heading of $\mu$ í $\mu$ ¡ıs, any attempt to reconcile all of these passages must say how this is so and, if possible, why Plato does not mention the mimetic aspect of poetry with simple narration in these passages.

Earlier I suggested that the key to answering the first question will come from seeing how meter is mimetic and that the discussion of rhythm will be of help here. In Socrates' view, rhythm represents character through its combinations of feet, although he is himself unsure about which combinations represent which characters. If we take the same view of meter, we can readily see how all poetry (that is, metered speech) is mimetic. Moreover, all poetry on this account represents features that are extremely important to the Guardians' education, namely the sorts of character traits that are either desirable or undesirable. The relevance, then, of all forms of poetry, even kinds that do not contain any first-person narration like dithyrambs, to Platonic critique now makes quite a lot of sense.

But now we are even deeper into the second question from above. Why doesn't Plato here mention the other ways that poetry can be mimetic, if that is so important? I submit that this is because Socrates needs the discussion of rhythm, which would only take place later, in order 
Forthcoming in Julia Pfefferkorn and Antonino Spinelli (eds.), Platonic Mimesis

Reconsidered (Academia). Please cite published version.

to make this clear. In his transition from discussion of $\lambda$ ó $\gamma 0 \varsigma$ to $\lambda \dot{\varepsilon} \xi 1 \varsigma$, Socrates first discusses ways of making $\mu$ í $\mu \eta \sigma \varsigma$ that are linguistic in nature (e.g., the choice of pronouns) and only later considers the more musical accoutrements such as harmony and rhythm.

\section{Conclusion}

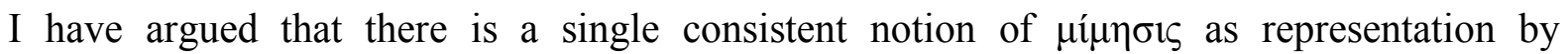
resemblance in Plato's Republic. I have not yet shown how this notion can play the role Plato intends in his criticism of poetry. ${ }^{40}$ An in-depth exploration of these issues goes well beyond the scope of this paper. In conclusion, however, I will say something briefly about how my account can elucidate Socrates' criticism. I will suggest that, although there is but one conception of $\mu$ í $\mu \eta \sigma \varsigma \varsigma$ throughout, Socrates focuses on different aspects of that account in different passages.

Book III's critique is centered on the educational role of the mimetic arts and their effects on prospective guardians. Here it is notable that the mimetic objects discussed in these passages are character traits. Plato is particularly interested in the ways in which different forms of $\mu\{1 \mu \eta \sigma 1 \zeta$ give rise to different sorts of characters, since this is of course crucial if we will have a just city. The aspect of the mimetic arts that is most relevant in this context turns out to be that they come about by resemblance. The resemblance to both good and bad character traits is essential to the psychological mechanism that can lead souls in good or bad directions. In Book X, by contrast, what is most important is that $\mu$ í $\mu \eta \sigma ı$ is a sort of representation. Here the fact that it is representational and it represents not forms but sensibles is crucial to Socrates' argument that the poets can create their artworks without any knowledge of what they are discussing ( $598 \mathrm{~d} \mathrm{ff}$ ). The fundamental problem, it seems, is that people like Homer were taken to be very knowledgeable about the topics of their poems simply because those poems were beautiful. Socrates objects that, because they have only created representations of appearances, no knowledge of anything beyond those appearances was necessary for the creation of the artwork. Indeed, Homer could unknowingly represent good characters as bad and vice versa, which, if we take pleasure in that representation, distort our own images of what is good and bad. Together with the psychological story of Books II-III, this raises the seriously dangerous possibility that Homeric poetry could harm citizens if presented as an ethical ideal.

\footnotetext{
${ }^{40}$ On this, see Ferrari 1990.
} 
Forthcoming in Julia Pfefferkorn and Antonino Spinelli (eds.), Platonic Mimesis Reconsidered (Academia). Please cite published version.

There is, of course, much more to be said about how the notion of $\mu$ í $\mu \eta \iota_{\varsigma}$ can elucidate Plato's critique of the arts. What I hope to have shown is that attention to the wide variety of, especially musical, arts can shed significant light on those well-trodden passages on poetry. 
Forthcoming in Julia Pfefferkorn and Antonino Spinelli (eds.), Platonic Mimesis

Reconsidered (Academia). Please cite published version.

References

Belfiore, E. (1984), A Theory of Imitation in Plato's Republic. In: Transactions of the American Philological Association 114, 121-146.

Cooper, J.M.; Hutchinson, D.S. (1996) (ed.), Plato. Complete Works, Indianapolis.

D’Angour, A.J. (2015), Sense and Sensation in Music. In: Destrée, P.; Murray, P. (eds.), A Companion to Ancient Aesthetics, Chichester, 188-203.

Fasko, M.; West, P. (2020), The Irish Context of Berkeley's 'Resemblance Thesis'. In: Royal Institute of Philosophy Supplement 88, 7-31.

Ferrari, G.R.F. (1990), Plato and Poetry. In: G.A. Kennedy (ed.), The Cambridge History of Literary Criticism, Cambridge, 92-148.

Goodman, N. (1976), Languages of Art. An Approach to a Theory of Symbols, $2^{\text {nd }}$ edition, Indianapolis.

Halliwell, S. (2002), The Aesthetics of Mimesis, Princeton.

Halliwell, S. (2009), The Theory and Practice of Narrative in Plato. In: Grethlein, J.; Rengakos, A. (eds.), Narratology and Interpretation. The Content of Narrative Form in Ancient Literature, Berlin/Boston, 15-41.

Halliwell, S. (2011), Plato. In: Gracyk, T.; Kania, A. (eds.), The Routledge Companion to Philosophy and Music, New York, 307-316.

Klavan, S. (2019), Melody and Meaning. The Semiotics of Ancient Greek Music in the Late Classical and Early Hellenistic Eras, DPhil Dissertation, Oxford University.

Kulvicki, J.V. (2006), On Images, Oxford.

Lear, G.R. (2011), Mimesis and Psychological Change in Republic III. In: Destree, P.; Herrmann, F.G. (eds.), Plato and the Poets, Leiden, 195-216.

Lienemann, B. (2010), Die Argumente des Dritten Menschen in Platons Dialog »Parmenides«, Göttingen.

Lynch, T. (2016), Why are only the Dorian and Phrygian harmoniai accepted in Plato's Kallipolis? Lyre vs. Aulos. In: Bravi, L.; Lomiento, L.; Meriani, A.; Pace, G. (eds.), Tra lyra e aulos. Tradizioni musicali e generi poetici, Pisa/Bari, 267-84.

Moss, J. (2007), What is Imitative Poetry and Why is it Bad?. In: Ferrari, G.R.F. (ed.), The Cambridge Companion to Plato's Republic, Cambridge, 415-444. 
Forthcoming in Julia Pfefferkorn and Antonino Spinelli (eds.), Platonic Mimesis Reconsidered (Academia). Please cite published version.

Pappas, N. (2017), Plato's Aesthetics. In: Zalta, E.N. (ed.), The Stanford Encyclopedia of Philosophy (Fall 2017 Edition).

Pelosi, F. (2010), Plato on Music, Soul, and Body, Cambridge.

Peponi, A-E. (2009), Choreia and Aesthetics in the Homeric Hymn to Apollo: The Performance of the Delian Maidens (Lines 156-164). In: Classical Antiquity 28,1, 39-70.

Schofield, M. (2010), Music all pow'rful. In: McPherran, M. (ed.), Plato's 'Republic'. A Critical Guide, Cambridge, 229-248.

Slings, S.R. (2003) (ed.), Platonis Respublica, Oxford.

West, M.L. (1992), Ancient Greek Music, Oxford.

West, M.L. (2003), Homeric Hymns. Homeric Apocrypha. Lives of Homer. Cambridge, Mass.

Woerther, F. (2008), Music and the Education of the Soul in Plato and Aristotle: Homeopathy and the Formation of Character. In: The Classical Quarterly 58,1, 89-103. 